\title{
Implication of Legal References on Technological Dissemination: a Study on Transgenic Soybeans Resistant to Glyphosate Herbicide in Brazil
}

\author{
Roberta Lopes Rodrigues', Celso Luis Salgueiro Lage ${ }^{2}$,Alexandre Guimarães Vasconcellos ${ }^{3}$
}

\begin{abstract}
The following paper aims at establishing a connection between the evolution of legal landmarks related to soybeans tolerant to glyphosate-based herbicide in Brazil and the planting growth of this transgenic soybean in Brazil, in order to determine the role that such soybeans play in today's domestic agricultural scenario. To do so, a study of Brazilian laws that protect intellectual creations was carried out (Industrial Property Law - Law number 9.279/96 and the Plant Protection Law - Law number 9.456/97), the Law on Biosafety - Law number III05 / 05 - and the Law on Brazilian Seeds and Seedlings - Law number 10.71 I/03, in order to delimit the matter protected by each of those laws while establishing its interfaces. Regarding planting, the Biosafety Law of 2005 corresponds to the fourth law which deals with soybeans tolerant to glyphosate-based herbicide and ensures that those previously registered may be marketed without limitation per crop. In order to estimate the space that soybean seeds tolerant to glyphosate-based herbicide began to occupy in the Brazilian market, in the 2008/2009 harvest, compared to the other not genetically modified soybeans, a search in the Ministry of Agriculture's database was done (http://www.agricultura.gov.br) through the available records of certified, non-certified and basic seeds.

This study demonstrates that despite great controversy involving planting of transgenics and in particular the emblematic case of Roundup Ready soybeans, we found out that in Brazil there has been an evolution and articulation of legal landmarks in order to facilitate and make this market more attractive. In the case of soybeans tolerant to glyphosate-based herbicide (which had its production measured here) the market went from an estimated $40 \%$ in the $2005 / 2006$ harvest, according to James (2005) to $50.6 \%$ in $2008 / 2009$ indicating that Brazil has been following the trend of spreading transgenic planting as has been occurring in most parts of the globe.
\end{abstract}

Keywords: soybeans; glyphosate; roundup ready; gmo; seeds; industrial property law.

\footnotetext{
'Industrial Property Researcher, National Institute of Industrial Property (INPI). Rua Mayrink Veiga 9, $21^{\circ}$ andar. CEP: 20090-9I0. Rio de Janeiro, Rj, Brazil. Phone: +55 2I 30373543. E-mail: robertalopesrodrigues@yahoo.com.br

${ }^{2}$ Senior Specialist in Industrial Property and Permanent Professor of the Intellectual Property and Inovation Academy of National Institute of Industrial Property (INPI). Rua Mayrink Veiga 9, 20 andar. CEP: 20090-910. Rio de Janeiro, Rj, Brazil. Phone: +55 2130373543. E-mail: clslage@gmail.com

${ }^{3}$ Researcher in Industrial Property and Permanent Professor of the Intellectual Property and Inovation Academy of National Institute of Industrial Property (INPI). Rua Mayrink Veiga 9, 20ªndar. CEP: 20090-910. Rio de Janeiro, Rj, Brazil. Phone: +55 2130373543. E-mail:alexguim@inpi.gov.br
}

ISSN: 07 I8-2724. (http://www.jotmi.org)

Journal of Technology Management \& Innovation (c) Universidad Alberto Hurtado, Facultad de Economía y Negocios. 


\section{Introduction}

The agro-industrial segments or the Brazilian Commodity System Approach (BCSA), created in the 70s, are responsible for activities between different actors of purchases and sales of the agricultural system. During that time, they were responsible for the internalization of the machinery industry and agricultural inputs, the modernization and expansion of the agro-industrial system, and for setting up the apparatus of economic policy focused on agriculture and industries (Kageyama, 1990). Since the 90s, these segments have been the most modern and industrialized segments of the agricultural sector and currently can be named as Brazilian agribusiness. According to the definition of CSA, Goldberg (1968) agribusiness today already encompasses, "A Commodity System Approach encompasses all actors involved in the production, processing and distribution of a product. Such system includes the market for agricultural inputs, agricultural production, storage operations, processing, wholesale and retail delimiting a flow that goes from the inputs to the consumer. The concept encompasses all institutions that affect the coordination of following stages of the product flow, such as government institutions, futures markets and trade associations."(Gibertoni and Colenci, 2000).

Leme and Sousa (2000) pointed out that agribusiness is undergoing a strong restructuring process characterized by a concentration of capital in few companies. From this restructuring, companies incorporated a portfolio of patents that already met local needs, and therefore could minimize the steps for obtaining and marketing their products. This was observed by Leme and Sousa (2000) especially in the 90 s. At the time, several "good players" from the industry came into Brazil taking significant slices of the domestic market (Leme and Sousa, 2000), and providing a more competitive program for improving bean and soybean than the one offered by the public sector (Borém and Miranda 2007). By the late 90s, the top four companies were already in Brazil holding a 43\% share of the market, according to Leme and Sousa (2000).

In 200I, the five companies that stood out in the seeds market were: Monsanto, Dupont, Novartis, Aventis and Savia (Fonseca et al., 2004). In the plant improvement category, the companies were: Monsanto, Dupont / Pioneer and Syngenta (Borém and Miranda, 2007).

According to Rodrigues (2005), in 2005 Brazilian agribusiness had $39 \%$ of exports, $34 \%$ of GDP and $37 \%$ of the workforce, which emphasizes the segment's importance to the current insertion of the country in world trade. Among products, soybean has more prominence, given that from 1996-2005, the Ministry of Agriculture had already pointed out that the revenue generated by soybean alone increased from $\$ 1.018$ million to $\$ 5.345$ million (Bureau of Agricul- tural Policy 2008). Thus, soybean takes a position of importance as a domestic exporting product. Data taken from the Análise (2007) revealed that in 2004, soybean was the second product in the export agenda.

Literature suggests the entry of soybeans tolerant to glyphosate-based herbicide in Brazil was very similar to the entry in soybean producing neighboring countries, such as Argentina and Paraguay. This soybean found a quick and effective way into the informal seed market in order to reach a larger number of "consumers" (The World According to Monsanto, 2008. Also, these soybeans are resistant to one of the most widely used herbicides in the world, glyphosate ( $\mathrm{N}$-fosfometil glycine) Thus, the soybeans tolerant to glyphosate-based herbicide, as it is known generically, is in fact, many types of soybeans that have been genetically modified in order to be tolerant and resistant to glyphosatebased herbicides or RR soybeans, and therefore, are able to grow despite the presence of this herbicide.

As the soybeans exported by Brazil showed traces of transgenics, the government felt pressure to position itself on the planting of soybeans, marketing of soybeans tolerant to the glyphosate-based herbicide and felt pressure to discuss mechanisms to financially reward the holders of protected technologies connected with soybeans tolerant to glyphosate-based herbicide.

After the entry of soybeans tolerant to glyphosate-based herbicide, some countries, like Argentina increased their soybean exports (Lence and Hayes, 2005). However, it is difficult to obtain data on the influce that glyphosate-tolerant soybeans had on the economy of thoses countries.

Given the important role that soybean plays in the Brazilian economy and the scarcity of data on the spread of technology on glyphosate-resistant soybean in Brazil, this study aims to identify the proportion this modified soybean has in the Brazilian market. Also, this article deals with the hypothesis that the establishment of a legal apparatus, allowing for the soybean's intellectual protection and technologies on soybean toleranct to glyphosate herbicide, marketing and certification of soybean quality, was necessary to generate legal security and facilitate the spread of technology on glyphosate-tolerant soybean on the Brazilian seed market with legal support.

\section{Materials and Method}

The Brazilian legal apparatus on Soybeans Tolerant to glyphosate-based herbicide Or RR Soybeans

An analysis of Brazilian law connected with this study's tolerant soybeans is essential to delineate the space occu- 
pied by tolerant soybeans in the Brazilian market, since the presence of these laws created a safe environment for both intellectual protection of inventions connected to these soybeans and their marketing. The current laws are: the Industrial Property Law (Law Number 9.279/96), the Plant Cultivar Protection Law (Law Number 9.456/97), the Biosafety Law (Law Number I I.105/05) and the Brazilian Seeds and Seedlings Law (Law Number 10.7I I/03).

\section{Estimate on Soybean Seeds Tolerant to Glyphosate or RR Soybeans}

To estimate the amount of RR soybean seeds available for purchase in the market, data from the Agricultural Zoning on the Ministry of Agriculture's website was used (http:// www.agricultura.gov.br).

The Agricultural Zoning indicates annually the cultivars that adapted to different regions and have available certified seeds, according to the information sent by the seed producer (obtainer or maintainer) to the General Coordination of Agricultural Zoning and Livestock. In order to be nominated for Zoning, cultivars must be registered in the National Registry of Cultivars (RNC) of the Ministry of Agriculture, Livestock and Supply-MAPA (MAPA, 2008).

For a better understanding of this study, it is necessary to explain the meaning of particular vocabulary in this field. According to Borém and Miranda (2007), genetic seed is seed produced by agencies, usually public, which develop the cultivar. It is used to produce basic seed through seed multiplication. Basic seed is the seed used to produce certified seed through multiplication and is developed by seed producers, which are typically represented by private initiative. The certified seed is the seed commercially available and is used by farmers for obtaining grain. This seed's certification process occurs through production inspection at all stages of production by the Ministry of Agriculture, Livestock and Supply (MAPA) or by the certifying entity, which may be a private company accredited by MAPA. At the end, the certified seed receives a quality certificate (Eichelberger, 2009 Brazil, 2003b) and is registered by the seed producer in accordance with the rules from the National Registry of Cultivars (RNC). The non-certified seeds are those obtained from the multiplication of, at most, two generations of the certified seeds, basic seeds or genetic seeds. But unlike certified seeds, the multiplication of non-certified seeds is controlled by the certified seed producer accredited by MAPA and carried out in seed production fields enrolled in MAPA (Eichelberger, 2009; Brazil, 2003).

Therefore, in order to measure the soybean seeds tolerant to glyphosate-based herbicide in the Brazilian market, this study categorized the seeds: basic RR soybean seeds, genetic RR soybean seeds, certified RR soybean seeds and non-certified RR soybean seeds and non-RR soybeans or basic conventional soybean seeds, genetic, certified and noncertified. Considering that both certified seeds and noncertified seeds can be used to obtain the grain, both seed types were used for this study so as to estimate the amount of seeds available for planting.

The data on soybean cultivars are from the 2008/2009 harvest. From them, it was possible to obtain: a) the total (in tons) of conventional soybean seeds available, such as genetic, basic and certified b) the amount (in tons) of conventional certified soybean seeds ( $\mathrm{Cl}$ and $\mathrm{C} 2), \mathrm{c}$ ) the total (in tons) of certified RR soybean seeds ( $\mathrm{Cl}$ and $\mathrm{C2}$ ), d) the total amount (in tons) of non-certified conventional soybean seeds and e) the amount (in tons) of non-certified RR soybean seeds.

Calculation I: In order to obtain the percentage of RR soybean seeds among all available seeds, the total amount (in tons) of RR soybean seeds (genetic RR seeds, basic seeds, certified seeds and non-certified seeds) was divided by the total (in tons) of RR soybean seeds and conventional seeds (certified seeds, basic seeds, genetic seeds and non-certified seeds), and the result multiplied by 100 .

Calculation 2: In order to obtain the percentage of certified and non-certified RR soybean seeds among all RR soybean seeds (genetic seeds, basic seeds, certified seeds and non-certified seeds), only the total (in tons) of certified RR seeds ( $\mathrm{Cl}$ and $\mathrm{C} 2$ ) and non-certified RR seeds was divided by the total (in tons) of RR seeds (genetic seeds, basic seeds, certified seeds and non-certified seeds), and the result multiplied by 100 .

\section{Results}

The Brazilian Legal Apparatus on Soybeans Tolerant to Glyphosate-Based Herbicide.

\section{The Industrial Property Law}

(Law Number 9.279/96)

After the signing and ratification of the TRIPS Agreement, Brazil published a law of industrial property protection consistent with the provisions of the international agreement. Therefore, on 05/14/96, the Industrial Property Law Number $9.279 / 96$ was enacted, which now offers protection for technological areas that were not benefited by the previous legislation - CPI 5.772/7I (Brazil, 1996). Among these areas is the process of obtaining genetically modified plants, and specifically the inventions directed to confering the transformed organism some tolerance to the glyphosate-based herbicide. 
On the other hand, plants (kingdom Plantae) isolated from nature and the transgenics, such as soybeans tolerant to the glyphosate-based herbicide, are not protected by the LPI because they are not inventions and not patentable matter by this law.

\section{The Cultivars Protection Law} (Law Number 9.456/97)

As far as protection of plants, the TRIPS Agreement establishes in Article 27.3 that such protection should be given: a) in the form of patents through each country's Industrial Property, b) as a sui generis mechanism; c) or by combining the two forms of protection.

In Brazil, the protection of a cultivar was only made possible with the enactment of the Brazilian Cultivar Protection Law (LPC) or Law Number $9.456 / 97$ of 04/25/97. This legal provision is in line with the TRIPS Agreement since it is a sui generis system of plant protection. Furthermore, the LPC is based on the UPOV5 Act of 1978, of which Brazil is a signatory, and incorporates some of the concepts expressed in the UPOV Act of 1991. This law outlines in its Article 2 that it is the only form of protection of a cultivar that could stop the free use of plants and its reproduction and multiplication parts in Brazil (Brazil, 1997). Besides the new cultivar, the essentially derived cultivar may also be protected, ie, the cultivar that was developed from a previously protected cultivar. The production and marketing of the cultivar and the reproduction and multiplication materials coming from the derived cultivar should be made with the obtainer's authorization. Therefore, soybeans tolerant to glyphosate-based herbicide and adapted to the soil and climate in Brazil, which is an essentially derived cultivar, is a result of the breeding of soybeans adapted to the soil and climate in Brazil and the soybeans tolerant to the glyphosate-based herbicide, and therefore can only be intellectually protected by Law Number 9.456/97.

\section{The Biosafety Law}

(Law Number I I. I05/05)

From the sum of several important factors, among which it is worth highlighting the new technologies developed in the 70 s in the area of recombinant DNA and also by the influence of the Convention on Biological Diversity, approved in 1992 in Rio de Janeiro during the United Nations Conference on Environmental Issues (ECO-92), Brazil enacted its first law dealing with biosafety, Law Number 8.974/95, from $01 / 08 / 95$. The issues dealt with by this law include the creation of the Technical Commission on Biosafety or CTNBio who issues a conclusive technical report on activities involving products with GMOs - Genetically Modified Organisms - including those from foreign countries and who wish to be introduced for marketing or manufacturing in the country. In addition, the first biosafety law establishes safety standards and enforcement mechanisms when using genetic engineering techniques in favor of life and human health, animal health, plant health and environmental health (Brazil, 1995).

On September 24th, 1998, CTNBio issued a report stating that the use of soybean cultivar GST 40-3-2 or its progenesis showed no evidence of risk to the environment or human or animal health. However, the report conditioned the granting of license for commercial planting to the monitoring of production areas of soybean cultivars derived from this strain for a period of 5 years. During this period, there would be a search for data from comparative studies in order to investigate the potential for significant changes to local biosafety. In case of alteration, commercial production could be suspended. This report, according to Art. 7 from the Biosafety Law at the time, Law Number 8.974/95 (Brazil, 1995), was conclusive and addressed the activities, consumption or any release of soybean GST 40-3-2 or its progenesis into the environment. However, when the first Biosafety Law went into effect (Law Number 8.974/95) the Ministry of Agriculture and Supply had to intervene by issuing permits and records relating to products and activities which used GMO intended for use in agriculture, livestock, aquaculture, agribusiness and related areas, in order to get authorization to plant such soybean.

Despite the authorization to plant and market the soybean tolerant to glyphosate-based herbicide had been issued in 1998, the planting was only allowed from 2003 on, due to a series of injunctions and lawsuits filed, against the CTNBio report.

Upon finding planting activity of this soybean, the government at the time issued a series of Provisional Measures (PMs), beginning in 2003, in order to provisionally "legalize" genetically modified soybean seeds reserved from the previous harvest. Thus, from 2003 to 2005 three PMs were edited to meet the same goal (Brazil, 2003a, Brazil, 2003c, Brazil, 2005a). In March 2005, a second Biosafety Law was published, Law Number I I. 105/05, of 03/24/2005, which, among other provisions, permanently authorized the planting and marketing of registered genetically modified soybean seeds .

The second Biosafety Law, Law Number I I.105/05, has an interface with the present work when establishing rules on marketing of GMOs, providing for the release of production and marketing of genetically modified soybean seeds that are tolerant to glyphosate-based herbicide and registered on the National Registry of Cultivars (Brazil, 2005b). Furthermore, this law is the second law that deals with the marketing and inspection of GMOs in general, but it is the fourth law that deals directly with soybeans tolerant to glyphosate- 
based herbicide. The enactment of this law cancels the first Biosafety Law (Law 8.794/95) and also revokes both Law Number 10,688, from 6/13/03 and Articles 5, 6, 7, 8, 9, 10 and 16 of Law Number 10,814, from 12/15/03.

Regarding genetically modified soybeans, the Biosafety Law Number II.105/05 specifically prohibits the marketing of its production as seed from the 2004/2005 harvest, makes provisional records established by Law 10.814/2003 permanent and authorizes the production and marketing of genetically modified soybean cultivar seeds tolerant to glyphosate registered on the National Registry of Cultivars - RNC of the Ministry of Agriculture, Livestock and Supply. Although the term "provisional registration", from Law Number 10.8I4/2003, is not clearly defined in any law, this term indicates that an effective record of soybeans tolerant to glyphosate-based herbicide in the RNC was about to come. Then, in 2005, with the enactment of the Biosafety Law, a conversion from "provisional registration" of soybean seeds tolerant to glyphosate-based herbicide to permanent record was possible.

By Law Number I I. 105/05, planting the "saved seeds" from 2004 , constituting the 2004/2005 harvest, is permitted, but its marketing can not occur in the form of seeds, only in the form of grains. In its sole paragraph, the article mentioning this permition explains that there may be an extension of that permition. Article 35 from the Biosafety Law authorizes the production and marketing of genetically modified soybean cultivar seeds tolerant to glyphosate registered on the National Registry of Cultivars - RNC of the Ministry of Agriculture, Livestock and Supply. While Article 36 authorizes the planting of genetically modified soybean seeds tolerant to glyphosate, reserved by farmers for their own use in 2004/2005 harvest and prohibits the production marketing as seed (Brazil, 2005a).

\section{Brazilian Law on Seeds and Seedlings} (Law Number 10.7I I/03)

On August 5, 2003, the second Brazilian Law on Seeds, Law Number 10.7II, was passed and deals specifically with the marketing, certification, inspection and use of seeds, as well as the activities of the National Registty of Seeds - RENASEM and activities of the National Registry of Cultivars - RNC (Brazil, 2003b).

This legal tool establishes that the production, processing and marketing of seeds and seedlings in Brazil, are subject to the registration of the cultivars on the National Registry of Cultivars-RNC. Brazilian Law on Seeds and Seedlings (LBSM) is a landmark in the seeds and seedlings area because it determines that only registered seeds may be marketed in the country and on the certification and inspection of seeds and seedlings, the Law guarantees the identity and quality of multiplication material and plant breeding produced nationwide.

\section{Synthesis of Legal Apparatus Related to Soybeans Tolerant to Glyphosate-based Herbicide}

For a better view of the major necessary landmarks for marketing soybeans tolerant to glyphosate-based herbicide in Brazil, a timeline was drawn below (Figure I).

(I) Publishing of Ist Biosafety Law - Law number 8.974, from 01/08/95.

(2) Publishing of Industrial Property Law - Law number 9.279, from 05/14/96.

(3)(a) Publishing of Cultivars Protection Law - Law number 9.456, from 04/25/97. (b) Publishing of first contract between Embrapa and Monsanto for production of a cultivar of soybeand toleranto to glyphosatbased herbicide.

(4) Issuance of technical report to subsidize the commercial approval of soybean cultivar GTS $40-3-2$ by CTNBio, in 09/14/98.

(5) Publishing of second contract between Embrapa and Monsanto for the production of a soybean cultivar tolerant to glyphosate-based herbicide.

(6) Identification of Ist non-authorized crop of soybean tolerant to glyphosate-based herbicide.

(7)(a) Publishing of law number 10.688 (MP II3/03) and number 10.814 (MP I3I/03) which allowed marketing of glyphosate-based soybeans from specific harvests. (b) Suspension of sentence which prevented the marketing of tolerant soybean cultivars until the definition of biosafety rules for labeling and presenting of an environmental impact study.

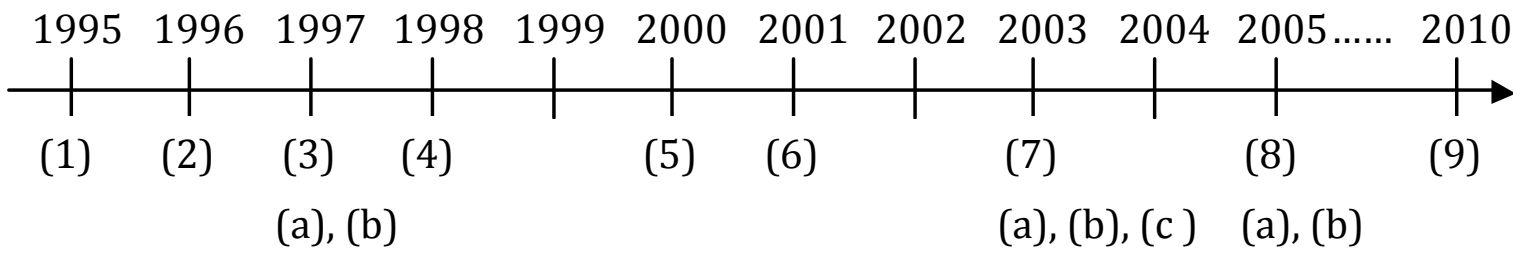

Figure I - The timeline co-relates the year with the main event(s) that was(were) significant to determine the marketing of soybeans tolerant to the glyphosate-based herbicide in Brazil.

ISSN: 07 I8-2724. (http://www.jotmi.org)

Journal of Technology Management \& Innovation (c) Universidad Alberto Hurtado, Facultad de Economía y Negocios. 
(c) Publishing of 2nd Brazilian Law on Seeds and Seedlings Law number $10.71 \mathrm{I}$, in 08/05/2003.

(8) (a) Publishing of Law number 11.092 (PM 223/05). (b) Publishing of 2nd Biosafety Law - Law number II.I05, in 03/24/2005.

(9) Expiration year of the last pipeline patent owned by Monsanto whose Monsanto Embrapa contracts are supported.

In this figure, the regulatory landmarks that have been published over ten years (1995-2005), are represented. From them, it was possible to intellectually protect tolerant soybean cultivars (1997), to patent technologies embedded in these cultivars (1996), to market tolerant soybeans (20032005 ) and to guarantee that quality certified seeds could be marketed in the country (2003). In this timeline, we can also see the years when contracts were signed between Embrapa and Monsanto for the production of tolerant cultivars (1997 and 2000), the year of publishing of the technical report by CTNBio (1998) and the year of sentence suspension that prevented the marketing of tolerant soybeans (2003). In other words, in the late 90's there was the enactment of laws that catered to intellectual protection (through patents and the sui generis mechanism) of matters related to soy- beans tolerant to glyphosate-based herbicide. Between 2000 and 2005 , there was uncertainty regarding the commercial release of soybeans tolerant to glyphosate-based herbicide, which only occurred in a wide and unrestricted way in 2005 with the publishing of the 2nd Biosafety Law (Law Number I I. 105/05). After setting up an apparatus that provided legal safety to plant soybeans tolerant to glyphosate-based herbicide within the business model devised by the company, the road for this type of soy to reach more space in the Brazilian agricultural scenario was created, given that Brazilian farmers identified the possibility of increasing their profit margins with the use of new technology.

\section{Quantification Of Soybean Seeds Tolerant to Glyphosate-based Herbicide}

From Tables I and 2, it is possible to estimate that slightly more than half of the soybean seeds commercially available (Table 3), meaning $50.6 \%$ (in tons), are RR soybean seeds (Calculation I) . In this estimate, based on data from Tables I and 2, are included genetic RR seeds, basic RR seeds, certified RR seeds and non-certified RR seeds for the 2008/2009 harvest. This result is corroborated with data published by

\begin{tabular}{|l|l|}
\hline Type of soybean seed & Total (in tons) \\
\hline non-certified soybean seeds & $3.285 .772,537$ \\
\hline Certified soybean seeds (CI e C2) & $474.390,34$ \\
\hline Genetic soybean seeds & 253,16 \\
\hline Basic soybean seeds & $4.746,32$ \\
\hline Soybean seeds & $\mathbf{3 . 7 6 5 . 1 6 2 , 3 5 7}$ \\
\hline
\end{tabular}

Table I - Total (in tons) of conventional soybean seeds and RR soybeans available for trading on the 2008/2009 harvests. Source: MAPA, 2008a.

\begin{tabular}{|l|l|}
\hline Type of soybean seed & Total (in tons) \\
\hline non-certified RR soybean seeds & 1.565 .080 \\
\hline Certified RR soybean seeds (Cl e C2) & $338.128,36$ \\
\hline Genetic RR soybean seeds & 181,44 \\
\hline Basic RR soybean seeds & $4.239,68$ \\
\hline RR soybean seeds & $\mathbf{1 . 9 0 7 . 6 2 9 , 4 8}$ \\
\hline
\end{tabular}

Table 2 - Total (in tons) of soybean seeds tolerant to glyphosate-based herbicide available for trading on the 2008/2009 harvests. Source: MAPA, 2008a. Tables I and 2 were created with data from the Agricultural Zoning published by the Ministry of Agriculture (MAPA, 2008).

ISSN: 07I 8-2724. (http://www.jotmi.org) 
Levien et al (2008) which indicate that the proportion (in percentage) of RR soybean seeds in Brazil has increased, since the harvest of 1999/2000 harvest after harvest. In this study, the "legal" seeds reached $40 \%$ in the 2007/2008 harvest and if we account for the "illegal" seeds, the total RR soybean seeds marketed in Brazil reached 62\% in that crop. Unfortunately, this publication did not inform the methodology employed. Thus, it is not possible to know how this counting was done, nor the type of RR soybean seeds accounted for - certified, non-certified, or basic or genetic.

To this is added the fact that $99.8 \%$ (in tons) of the total RR soybean seeds are certified and non-certified soybean seeds (Calculation 2). To achieve this result, represented in Table 4, the total amount of certified and non-certified RR soybeans was divided by the total amount of certified RR soybean seeds, basic RR soybean seeds, genetic RR soybean seeds and non-certified RR soybean seeds. This indicates that the remaining $0.2 \%$ (in tons) correspond to the genetic and basic RR soybean seeds.

\section{Discussion and Conclusions}

The legal apparatus built from the mid-90s until 2005, Industrial Property Law (LPI), Cultivars Protection Law (LPC), Biosafety Law and the Law of Seeds and Seedlings, allowed for the establishment of laws that permit the protection, marketing and guarantee the quality of commercial seeds to the consumer. As a result, soybeans tolerant to glyphosatebased herbicide reached the volume of seeds available in the market today ( $50.6 \%$ of total soybean seeds).

The extent of Industrial Property rights is represented by Law Number 9.279/96 (LPI), and the Protection of Cultivars rights (LPC), by Law Number 9.456/97. The LPI is now granting protection to unpatentable matters by the CPI 5.772/7I. Thus, the inventions relating to technologies that provide plants with tolerance to glyphosate-based herbicide are protected by patents. In turn, the protection of cultivars by the LPC allowed for the protection of plants, such as soybeans tolerant to glyphosate. Thus, both technologies with tolerance to glyphosate-based herbicide and plants which have such tolerance are objects of different protection laws and therefore are subject to different dictates.

Based on the Biosafety Law, Law Number I I.I05/05, both the marketing and the use of soybeans tolerant to glyphosate-based herbicide are allowed. Thus, the law closed a cycle of Provisional Measures that had been dragging from 2003 to 2005.

The Brazilian Law for the Protection of Seeds and Seedlings, Law No. $10.71 \mathrm{I} / 03$, has a more strict approach on the quality of seeds produced and circulating in the country's market, compared to the previous law from 60's. Law Number I0.7 I I/03 seeks to bring Brazil to new and demanding global agricultural standards, requiring enrollment in the RNC of all cultivars produced and marketed in Brazil and enforces inspections. Thus, this law aims to ensure, since 2003, that Brazil will offer a higher quality end product and will create a safer environment for investors in R\&D of new cultivars. Particularly, this law ensured that only the soybeans tolerant to glyphosate-based herbicide registered in RNC could be marketed.

Pessanha et al (2006) projected that the percentage of soybeans tolerant to glyphosate-based herbicide on 2001/2002 harvest, when the marketing of this soybean was still prohibited, represented $60 \%$ of genetically modified for tolerance to the glyphosate-based herbicide. Others, however, estimated that the harvest of 2005/2006, meaning, after the commercial release of the tolerant soybean, these soybeans would reach a number lower than $40 \%$ (James, 2005). Ac-

\begin{tabular}{|l|l|}
\hline & $\%$ of seeds \\
\hline RR soybean seeds & $50,6 \%$ \\
\hline Conventional soybeans seeds & $49,4 \%$ \\
\hline Total of RR soybean seeds and conventional soybean seeds & $100 \%$ \\
\hline
\end{tabular}

Table 3- Percentage (\%) of RR soybean seeds and seeds from conventional soybeans.

\begin{tabular}{|l|l|}
\hline & $\%$ of seeds \\
\hline Certified and non-certified RR soybean seeds & $99,8 \%$ \\
\hline Genetic and basic RR soybean seeds & $0,2 \%$ \\
\hline Total of certified, non-certified, genetic and basic RR soybean seeds & $100 \%$ \\
\hline
\end{tabular}

Table 4 - Percentage (\%) of certified RR soybean seeds, non-certified RR soybean seeds, genetic RR soybean seeds and basic RR soybean seeds.

ISSN: 07I 8-2724. (http://www.jotmi.org)

Journal of Technology Management \& Innovation (c) Universidad Alberto Hurtado, Facultad de Economía y Negocios. 
cording to Castro (2000), seed production tends to follow market demand, and therefore the estimate of circulating tolerant soybeans in the Brazilian market allows us to estimate the actual impact of such transgenic in the country's business scenario. So the fact that a little more than half of the soybean seeds available in Brazil (50.6\%) for buying and selling for the 2008/2009 harvest is made up by RR soybeans, shows that the Brazilian market is strongly looking for this type of seed. Since the soybean market in the international arena is pretty competitive, it is expected that the soybean producer will look for soy cultivars that maximize production, minimize costs, and provide a competitive product, and so will choose improved seeds, such as transgenic ones. Lawrence (2008) shows that the growth rate of planted acres of transgenic crops in Brazil was $28 \%$ in 2007 , surpassing the U.S.'s rate of $25 \%$. This reflects that Brazil has been following a global trend envisioned by James (2005) to increase the cultivation of Genetically Modified Organisms (GMOs). Furthermore, James (2005) indicates that the consumer acceptance for this type of cultivation is higher and that Brazil has been responding with more supply of GMOs.

Furthermore, most of the RR soybean seeds (99.8\%) available for planting are ready to generate RR soybean grains, since only $0.2 \%$ are RR soybean seeds that will still to be multiplied to become certified or non-certified. Therefore, it is hoped that with these results, the Brazilian production of RR soybean grains will be greater harvest after harvest.

Given the favorable legal setting for the protection of inventions connected to transgenic plants and circulation of its seeds in the Brazilian market, the increasing production of transgenic RR soybean seeds in Brazil and the worldwide trend to adopt this type of culture, the country must and can develop a strategy to go into the international market aimimg the development of domestic technological innovations. Particularly in cases where the patented technology can be inserted into new cultivars which may also be protected by intellectual property instruments in more competitive segments such as soybean, corn and cotton, the country can get more notoriety. In order to achive this, the State must regulate the seeds market through the adoption of public policies aimed at increasing inspection, at encouraging investment in Research \& Development from public and private sectors and aimed at providing efficient and competitive products.

\section{References}

ANALISE - Comércio Exterior. Anuário 2005-2006, (2007). Análise Editorial, São Paulo.

BOREM, A.; Miranda, G.V. (2009). Melhoramento de Plantas, UFV,Viçosa.

BRASIL. Lei ${ }^{\circ} 8.974$, de 5 de janeiro de 1995. Regulamenta os incisos II eV do $\S 1^{\circ}$ do Art. 225 da Constituição Federal, estabelece normas para $\circ$ uso das técnicas de engenharia genética e liberação no meio ambiente de organismos geneticamente modificados, autoriza o Poder Executivo a criar, no âmbito da Presidência da República, a Comissão Técnica Nacional de Biossegurança, e dá outras providências.

. Lei $n^{\circ} 9.279$, de 14 de maio de 1996. Regula direitos e obrigações relativos à propriedade industrial.

. Lei $\mathrm{n}^{\circ}$ 9.456, de 25 de abril de 1997. Institui a Lei de Proteção de Cultivares.

. Lei $n^{\circ} 10.688$, de 13 de junho de 2003a. Estabelece normas para a comercialização da produção de soja da safra de 2003 e dá outras providências.

. Lei $n^{\circ} 10.71$ I/03, de 05 de agosto de 2003b. Dispõe sobre o sistema nacional de sementes e mudas e dá outras providências.

. Lei $n^{\circ} 10.814$, de 15 de dezembro de 2003c. Estabelece normas para o plantio e comercialização da produção de soja geneticamente modificada da safra de 2004 , e dá outras providências.

. Lei $n^{\circ} 11$.092, de 12 de janeiro de 2005a. Estabelece normas para o plantio e comercialização da produção de soja geneticamente modificada da safra de 2005 , altera a Lei $n^{\circ} 10.814$, de 15 de dezembro de 2003 , e dá outras providências.

. Lei $n^{\circ}$ II.105, de 24 de março de 2005b. Regulamenta os incisos II, IV eV do $§ 10$. do Art. 225 da Constituição Federal, estabelece normas de segurança e mecanismos de fiscalização de atividades que envolvam organismos geneticamente modificados - OGM e seus derivados, cria o Conselho Nacional de Biossegurança - CNBS, reestrutura a Comissão Técnica de Biossegurança - CTNBio, dispõe sobre a Política Nacional de Biossegurança - PNB, revoga a Lei $n^{\circ}$ 8.974 , de 5 de janeiro de 1995, e a Medida Provisória $n^{\circ}$ 2.19I, de 23 de agosto de 2001 , e os art. $5^{\circ}, 6{ }^{\circ} 7^{\circ}, 8^{\circ}, 9^{\circ}$, 10 e 16 da Lei $n^{\circ} 10.814$, de 15 de dezembro de 2003, e dá outras providências.

ISSN: 07 I8-2724. (http://www.jotmi.org) 
CASTRO A. M. G. de. (2000). Análise da competitividade de cadeias produtivas. Workshop de Cadeias Produtivas e Extensão Rural na Amazônia. Embrapa, Manaus.

EICHELBERGER, L. (2009). Semente legal. http://www.portaldoagronegocio.com.br/conteúdo.php?id=23352.[Accessed December 17, 2009]

FONSECA, M. da G. D.; Poz, M. E. D.; da Silveira, J. M. F. J. (2004). Biotecnologia vegetal e produtos afins: sementes, mudas e inoculantes. In: da Silveira, J. M. F..; Poz, M. E.D.; Assad,A. L.(Org.) Biotecnologia e Recursos genéticos -desfios e oportunidades para o Brasil. Ed: Instituto de EconomiaUnicamp and FINEP, Campinas. pp. 165-200.

GOLDBERG, R.A. (1968). Agribusiness Coordination:A system approach to wheat, soybean and Florida orange economies. Division of Research. Graduate School of Business and Administration. Harvard University, Cambridge.

GILBERTONI, D.; Colenci Junior, A. (2000). Uma avaliação do sistema agroindustrial do leite brasileiro frente as estratégias empresariais e frente às novas tecnologias da informação. Anais do XX ENEGEP - Encontro Nacional de Engenharia da Produção - ENEGEP; São Paulo; Brasil. 2000. http://www.abepro.org.br/biblioteca/ENGEP2000_E0055. PDF. [Accessed September 15, 20I0].

GRIFFTHIS, A. F.; Miller, J. H.; Suzuki, D. T.; Lewontin, R. C.; Gelbart, W. M. (1998). An introduction to genetic analysis. [Trad. P.A. Motta]. Guanabara Koogan, Rio de Janeiro.

JAMES, C. (2005). Global status of commercialized transgenic crops: 2005, ISAAA Briefs No. 34, International Service for the Acquisition of Agri-biotech Applications, Ithaca, NY.

KAGEYAMA, A.; Buanain, A. M.; Reydon, B. P.; da Silva, J. G.; Silveira, J. M. J.; Fonseca, M. da G. D.; Ramos, P.; Fonseca, R. B.; Belik, W. (1990). O novo padrão agrícola brasileiro: do complexo rural aos complexos industriais. In: Delgado et al. Agricultura e Políticas Públicas. IPEA, Brasilia. Pp. II3 - II7; $185-203$.

KESAN, J. P.; Gallo, A.A. (2005). Property rights and incentives to invest in seed varieties: governmental regulations in Argentina.AgBioForum, 8, (2 \& 3), | I 8-1 26.

LAWRENCE, S. (2008). Brazil superpresses US in new transgenic crop plantings. Nature Biotechnology, 26 (3), 260.

LEMES, M. F. P.; Souza, E. L. L. (2000). Concentração no agronegócio e o sistema brasileiro de defesa da concorrência. Preços Agrícolas, 5 - 10.
LENCE, S. H.; Hayes, D. J. (2005). Technology fees versus GURTs in the presence of spillovers: world welfare impacts. AgBioForum, 8 (2 \& 3), I 72- 186.

LEVIEN,A.; Kohls, V.; Peske, S. (2008). A grandeza do negócio sementes de sementes no Brasil. In: Semente-inovação tecnológica, anuário 2008. Becker \& Peske, Rio Grande do Sul.

MAPA. Ministério da Agricultura, Pecuária e Abastecimento. (2008). O que é Zoneamento Agrícola de Risco Climático? http://www.agricultura.gov.br/portal/page_pageid $=33,1007023 \&$ dad=portal\&_schema=PORTAL. [Accessed November 10, 2008]

PESSANHA, L.; Wilkinson, J.; Castro, B., de; Moreno, C. (2006). Impactos sócio-econômicos e políticos da expansão do cultivo de soja transgênica sobre os agricultores na América Latina. In: CONGRESSO LATINO-AMERICANO DE SOCIOLOGIA RURAL,VI, 2006. Quito.Anais....ALASRU, Pp.I-20.

RODRIGUES, R. 2005. Mapa moderniza estrutura interna para apoiar crescimento do agronegócio. Rev. de Política Agrícola, I4 (I), 3-5.

SECRETARIA DE POLÍTICA AGRÍCOLA - MAPA. Exportações agropecuárias - Produtos selecionados. http://www. mapa.gov.br. [Accessed January 13, 2008]

THE WORLD ACCORDING TO MONSANTO. Director: Marie-Monique Robin. Produced by: Image and Campaigne, Art France, Productions Tahalie, National Film Board of Canada and WDR, 2008. DVD. 